\title{
Evaluation of Palmistichus elaeisis Delvare \& LaSalle (Hymenoptera: Eulophidae) as Parasitoid of the Sarsina violascens Herrich-Schaeffer (Lepidoptera: Lymantriidae)
}

\author{
Bruno Zaché (Corresponding author) \\ Department of Plant Production, School of Agronomic Sciences \\ Sao Paulo State University (UNESP) \\ ZIP Code 18610-307 Botucatu, SP - Brazil \\ Tel: 55-148-166-0514Ｅ-mail: bzache@bol.com.br \\ Ronelza Rodrigues da Costa Zaché \\ Department of Plant Production, School of Agronomic Sciences \\ Sao Paulo State University (UNESP) \\ ZIP Code 18610-307 Botucatu, SP - Brazil \\ Tel: 55-148-158-7624 E-mail: ronelzagro@yahoo.com.br \\ Carlos Frederico Wilcken \\ Department of Plant Production - School of Agronomic Sciences \\ Sao Paulo State University (UNESP) \\ ZIP Code 18610-307 Botucatu, SP - Brazil
}

Tel: 55-149-132-5761Ｅ-mail: cwilcken@uol.com.br

\author{
Received: October 12, 2011 \\ Accepted: December 15, $2011 \quad$ Published: March 1, 2012 \\ doi:10.5539/jps.v1n1p85 \\ URL: http://dx.doi.org/10.5539/jps.v1n1p85
}

\begin{abstract}
This is the first report on the parasitoid Palmistichus elaeisis, genus Eulophidae, found in the field parasitizing pupae of defoliating eucalyptus. Lepidopterous pests occur in eucalyptus plantations in Brazil, reaching high population levels. Due to the complexity of pest control in eucalyptus forests, alternative control methods have been proposed, for instance biological control through use of parasitoids. Natural enemies play an important role in regulating host populations because their larvae feed on the eggs, larvae, pupae or adults of other insects. The parasitic Hymenoptera are important agents in biological control programs against forest pests, and may provide economic and environmental benefits. The generalist endoparasitoid Palmistichus elaeisis Delvare and LaSalle, 1993 (Hymenoptera: Eulophidae) can develop in its host's pupae, which overcome the host's physiology and can therefore be used for biological control of agricultural and forest pests. This study aimed to evaluate the impact of $P$. elaeisis as a pupal parasitoid of $S$. violascens in providing a potential alternative to chemical control of the pest and creation of an alternative host. The experiment was developed in the Laboratory for Biological Control of Forest Pests, Universidade Estadual Paulista "Julio Mesquita Filho". Parasitoids used in this test were originally collected on pupae of E. eucerus. (Lepidoptera: Riodinidae) in eucalyptus plantations at Lençois Paulistas, São Paulo state, Brazil, in 2011. Thereafter, a laboratory culture has been maintained, using pupae of Spodoptera frugiperda (J. E. Smith) (Lep.: Noctuidae) as hosts. S. violascens eggs were collected in a eucalyptus clonal plantation in Sao Paulo state (Brazil). Larvae were reared under ambient conditions on Eucalyptus urophylla S.T. Blake (Myrtaceae) leaves. The following parameters were determined: parasitism level, numbers of emerged and non-emerged parasitoids and duration of egg-adult cycle. The $S$. violascens pupae were dissected to evaluate the non-emerged parasitoids. The parasitism level reached $100 \%$, with a $100 \%$ emergence rate. It was
\end{abstract}


verified that $113.2 \pm 0.8$ parasitoids emerged per individual pupa versus only $0.7 \pm 0.1$ that did not emerge. The $P$. elaeisis egg-adult cycle was $20.3 \pm 0.6$ days in $S$. violascens pupae. This opens new perspectives for utilizing this parasitoid in biological control programs against caterpillars important to forestry. Sarsina violascens in Brazil.

Keywords: Lepidoptera, Biological control, Sarsina violascens, Eulophidae, Pupal parasitoid

\section{Introduction}

Eucalyptus species were introduced into Brazil before 1900, to produce wood for railroad companies and timber production of fence posts and poles (Uhlig et al., 2008). The uses of wood from forests ranges from firewood, poles, fences, charcoal, pulp, paper, fibers and plates to more complex applications such as the manufacturing of houses, furniture and other structures, especially in the southern and soutneast regions of Brazil.

Also noteworthy is the growing demand for non-timber products such as resins, latex, food products, tannins and essential oils, as well as raw materials for the pharmaceutical industry such as medicinal plants. This tendency toward increasing demand for forest-based products is also worldwide (Ribaski et al., 2001). Areas with eucalyptus ecosystems represent the most stable agriculture and differ from natural vegetation or polycultures on account of their large areas planted with seedlings, which may favor the emergence of insect pests such as lepidopteran defoliators (Zanuncio et al., 2001; Zanuncio et al., 2003; Soares et al., 2007; Soares et al., 2009).

Defoliating caterpillars are the second most important group of pests on eucalyptus plantations in Brazil, ranking behind only leaf-cutting ants. In the past decade new species of eucalyptus-defoliating lepidopterans have appeared in Brazil. Sarsina violascens, also known as the purple moth, is a defoliating caterpillar native to Argentina and Brazil, belonging to the Order Lepidoptera, Family Lymantriidae (FAO, 2008; Zanuncio \& Lima, 1975).

It is known that this pest causes damage to the larval stage (caterpillar-induced defoliation). The attacks of defoliating caterpillars cause partial or total defoliation in plants. In the case of eucalyptus, the caterpillars interfere with the rate and balance of internal physiological processes of plants, affecting growth and formation of trunk biomass (Espindola \& Gonçalves, 2000). S. violascens presents a risk to human health, because it is a stinging caterpillar (Gallo et al., 2002).

Chemically, S. violascens can be controlled efficiency, but limitations include difficulty of applying insecticides, diminution of populations of natural enemies, the poisoning and contamination of the environment, increased costs and the emergence of resistant insects. This has motivated the search for other control methods to reduce the population density of this pest, with emphasis on the application of biological control (use of entomopathogenic bacteria, predatory stinkbugs and parasitoids), which enables the integration of pest management systems in forested areas. Natural enemies play an important role in regulating populations of their hosts because their larvae feed on the eggs, larvae, pupae or adults of other insects (Paron \& Berti Filho, 2000; Pennacchio \& Strand, 2006, Pereira et al., 2008a, 2008b; Zanuncio et al., 2008).

Alternative methodologies for control of Lepidoptera species in the forestry sector can present satisfactory efficiency (Zanuncio et al., 1994), especially biological control with parasitoids (Bragança et al., 1998). The parasitic Hymenoptera are important in biological control programs against forest pests, and may provide economic and environmental benefits.

The generalist endoparasitoid Palmistichus elaeisis Delvare and LaSalle, 1993 (Hymenoptera: Eulophidae) can develop in its host's pupae, which overcome the hosts physiology and can therefore be used for biological control of agricultural and forest pests (Bittencourt \& Berti Filho, 1999, 2004; Pereira et al., 2008 b). The lack of artificial diets requires the use of alternative hosts for the mass production of these wasps in the laboratory (Pereira et al., 2009).

Alternative hosts suitable for mass rearing of this parasitoid must be easily cultured at low cost and at an efficiency similar to that of natural hosts (Bittencourt \& Berti Filho, 1999; Paron \& Berti Filho, 2000; Ramalho \& Dias, 2003; Pereira et al., 2009).

The objective of this study was to evaluate the impact of P. elaeisis as a pupal parasitoid of S. violascens in providing a potential alternative to chemical control of the pest and creation of an alternative host.

\section{Materials and Methods}

The experiment was developed in the Laboratory for Biological Control of Forest Pests, Universidade Estadual Paulista "Julio Mesquita Filho". Parasitoids used in this test were originally collected on pupae of E. eucerus. (Lepidoptera: Riodinidae) in eucalyptus plantations at Lençois Paulistas, São Paulo state, Brazil, in 2011. Thereafter, a laboratory culture has been maintained, using pupae of Spodoptera frugiperda (J. E. Smith) (Lep.: 
Noctuidae) as hosts. Larvae were transferred to the laboratory, put in plastic containers with capacity of $50 \mathrm{ml}$, sealed with acrylic lids containing artificial diet consisting of $59.3 \mathrm{~g}$ of germ wheat, $38 \mathrm{~g}$ of yeast extract, $3.82 \mathrm{~g}$ ascorbic acid, $1.23 \mathrm{~g}$ of sorbic acid, $1.3 \mathrm{ml}$ of propionic acid, $0.131 \mathrm{ml}$ of phosphoric Nipagin $2.36 \mathrm{~g}, 123.6 \mathrm{~g}$ of beans, $15.35 \mathrm{~g}$ of agar and $3.1 \mathrm{~g}$ of formaldehyde.

The laboratory temperature was $26 \pm 2^{\circ} \mathrm{C}$ with relative humidity of $70 \pm 10 \%$. The pupae obtained were placed in glass tubes $14 \mathrm{~cm}$ long and $2 \mathrm{~cm}$ in diameter closed with "voile" fabric containing 15 females of $P$. elaeisis that had previously copulated for 24 hours and been fed pure honey for a period of 72 hours to test for the occurrence of parasitism; they were packed in plastic trays in a climatized room at $26 \pm 2{ }^{\circ} \mathrm{C}, 70 \% \mathrm{RH}$ and 12-hour photoperiod until adult emergence After 21 days the emerged parasitoids were used in this experiment.

S. violascens eggs were collected in eucalyptus clonal plantation in Sao Paulo state (Brazil). Larvae were reared under ambient conditions on Eucalyptus urophylla S.T. Blake (Myrtaceae) leaves and kept in a wooden cage (70x50x40 cm) with a glass front, at $25 \pm 1{ }^{\circ} \mathrm{C}, 70 \pm 10 \%$ relative humidity and 14-hour photophase. Upon pupation, 15 pupae were offered to $P$. elaeisis females at a 10:1 (parasitoid: host) ratio for 72 hrs. Thereafter, the females were removed and containers with $S$. violascens pupae were kept packed in plastic trays in a climatic chamber at $26 \pm 2^{\circ} \mathrm{C}, 60 \pm 10 \%$ relative humidity, and a 12-hour photophase.

The following parameters were determined: level of parasitism, number of emerged and non-emerged parasitoids, sex ratio and duration of egg-adult cycle. The pupae of $S$. violascens were dissected to evaluate the non-emerged parasitoids. The sexing of adults was performed according to Perreira et al. (2006).

The statistic used to evaluate the experimental parameters was randomized. The data were subjected to analysis of variance (ANOVA) and means were compared by Tukey test at $5 \%$ probability for parametric data. Nonparametric data were submitted to Kruskal-Wallis test $(\mathrm{p} \leq 0.05)$.

\section{Results and Discussion}

The parasitism level reached $100 \%$, with a $100 \%$ emergence rate. It was verified that $113.2 \pm(0.8 \mathrm{SE})$ parasitoids emerged per individual pupa versus only $0.7 \pm(0.1 \mathrm{SE})$ that did not emerge, sex ratio $0.85 \pm(0.3 \mathrm{SE})$. The P. elaeisis egg-adult cycle was $20.3 \pm(0.6 \mathrm{SE})$ days in $S$. violascens pupae. This suggests a host effect on parasitoid development time as reported for other species of parasitoids (Zago et al., 2006; Pastori et al., 2008; Pereira et al., 2008; Fávero, 2009).

Tetrastichinae is a major subfamily of Eulophidae, and has as hosts representatives of 100 insect families of different orders (Lasalle, 1993; Lasalle \& Schauff, 1995). A new Tetrastichinae species was described as Palmistichus elaeisis (Hym.: Eulophidae) The eggs of P. elaesis are hyaline, smooth, typically hymenopteriform and present a narrower anterior. The egg hatching period persists for approximately 48 hours. The first instar larvae are Apodans with transparent cuticle and hymenopteriform format with 12 segments; the larvae of the second, third and fourth instars (5 to 10 days) are whitish and segmentation is well defined. The larval stage lasts $8.04 \pm 0.17$ days. The pre-pupa is white with pigmented appendages. The pre-pupal stage was approximately 24 hours. The pupal period lasts on average $9.8 \pm 0.17$ days. These data were obtained utilizing the following hosts: A. gemmatalis, D. saccharalis, H. virescens, S. frugiperda and T. arnobia (Pereira et al., 2008).

P. elaesis has been reported in pupae of Eupseudosoma involuta (Sepp, 1852) (Lep.: Arctiidae) and Euselasia eucerus Hewitson, 1872 (Lep.: Riodinidae) (Delvare \& Lasalle, 1993), Sabulodes sp. (Lep.: Geometridae) (Bittencourt and Berti Filho, 1999) and Thyrinteina arnobia (Stoll, 1782) and Thyrinteina leucoceraea (Rindge, 1961) (Lep.: Geometridae)(Pereira et al., 2008). Le Verdier and Genty (1988) found that the natural control by Hispoleptis subfasciata of Pic (Col.: Chrysomelidae), a defoliating pest of Elaeis guineensis Jacq. (palm oil), was performed by a parasitoid which was later identified as $P$. elaeisis. The generalist behavior of $P$. elaeisis characterizes this natural enemy as a promising agent for utilization in biological control programs.

Under similar conditions as the host Zophobas confusa Gebien, 1906 (Coleoptera: Tenebrionidae) we found the following results from $P$. elaeisis in pupae of $Z$. confusa: respective percentages of parasitism and emergence were $100.00 \%$ and $64.28 \%$ and duration of life cycle was $28.78 \pm 1.47$ days. The progeny was $133.78 \pm 21.95$ offspring per parasitoid pupa per host, and the sex ratio $0.87 \pm 0.03$.

The life cycle of $P$. elaeisis in pupae of T. molitor, A. gemmatalis, D. saccharalis, S. frugiperda, Z. confuse, $T$. arnobia or H. virescens, ranging from 18.9 to 23.42 days (Bittencourt \& Berti Filho, 2004; Pereira et al., 2008b; Zanuncio et al., 2008).

The progeny of $P$. elaeisis of $S$. violascens pupae was greater than those in pupae of T. arnobia, A. gemmatalis and T. molitor (Pereira, 2006; Zanuncio et al., 2008). For gregarious parasitoids, the graphic relationship between the variables "number of parasitoids emerging from one host" and "burden placed on host parasitoids" is represented 
by a parabola that increases as a function of the number of positions on a host, in turn augmenting the number of parasitoids emerging from the same up to a limit that the author calls the load of the host, where there is no emergence of parasitoids (BECKAGE \& Alleyne, 1997).

The sex ratio of $P$. elaeisis offspring in pupae of $S$. violascens was lower than in pupae of Bombyx mori Linnaeus, 1758 (Lepidoptera: Bombycidae) (0.94-0.96), A. gemmatalis (0.96), T. molitor (0.94) and D. saccharalis (0.89) (Bittencourt and Berti Filho 1999, Pereira 2006, Zanuncio et al., 2008). However, the sex ratio was satisfactory, because there was greater production of $P$. elaeisis females, which are responsible for parasitism and production of future (Gonzáles et al., 2004; Silva- Torres \& Matthews, 2003).

Palmistichus elaeisis showed adequate reproductive performance in pupae of $S$. violascens, thus enabling the conclusion that this host can be used for mass rearing of P. elaeisis in the laboratory. Its generalist behavior and ease of being created in large quantities characterize Palmistichus elaeisis as a promising agent for use in control of lepidopteran eucalyptus defoliators. Research is being conducted by the Laboratory Biological Control of Forest Pests "Universidade Estadual Paulista Julio Mesquita Filho" São Paulo, Brazil, to provide a design methodology for mass rearing and release techniques by which P. elaeisis might control pests in eucalyptus plantations and thereby reduce the use of chemical and biological insecticides that would otherwise be employed to this end.

\section{References}

Bittencourt, M.A.L., \& Berti Filho, E. (1999). Preferência de Palmistichus elaeisis por pupas de diferentes lepidópteros praga. Scientia Agricola, Piracicaba, 56(4), 1281-1283.

Delvare, G., \& Lasalle, J.A. (1993). New genus of Tetrastichinae (Hymenoptera: Eulophidae) from the Neotropical region, with the description of a new species parasitica on key pests of oil palm. Journal of Natural History, London, 27(1), 435-444. http://dx.doi.org/10.1590/S1806-66902010000400028

Espindola, C.B., \& Gonçalves, L. (2000). Biologia de Oxydia vesulia (Cramer, 1779) (Lepidoptera:Geometridae). Floresta e Ambiente, 7(1), 80-87.

FAO. Overview of Forets Pests. (2008). Argentina. Forestry Department. Food and Agriculture Organization of the United Nations, 1, 22.

Gallo, D., Nakano, O., Silveira Neto, S., Carvalho, R.P.L., Baptista, G.C.De, Berti Filho, E., Parra, J.R.P., Zucchi, R.A., Alves,S.B., Vendramim,J.D., Marchini, L.C., Lopes, J.R.L., \& Omoto, C. (2002). Entomologia Agrícola, Piracicaba:FEALQ, p. 920.

Gauthier, N., Lassale, J. Quicke, D.L.J., \& Godfray, H.C.J. (2000). Phylogeny of Eulophidae (Hymenoptera: Chalcidoidea), with a reclassification of Eulophinae and the recognition that Elasmidae are derived eulophids. Systematic Entomology, London, 25(1), 521-539. http://dx.doi.org/10.1046/j.1365-3113.2000.00134.x

Hansson, C. (2004). Eulophidae of Costa Rica. Memoirs of the American Entomological Institute, Gainesville, $75,537$.

Lasalle, J. (1993). North American genera of Tetrastichinae (Hymenoptera: Eulophidae). Journal of Natural History, London, 28(1), 109-236. http://www.tandfonline.com/doi/pdf/10.1080/00222939400770091

Lasalle, J., \& Schauff, M.E. (1995). The chalcidoid families. Eulophidae, Oxford: Oxford University Press, 1, 315-329.

Noyes, J.S. (1998). Catalogue of the Chalcidoidea of the World. Amsterdam: ETI Eletronic Publication. (CD-ROM).

Pereira, F.F., Zanuncio, J.C., Serrão, J.E., Oliveira, H.N., Fávero, K., \& Grance, A.L.V. (2008). Progênie de Palmistichus elaeisis Delvare \& LaSalle (Hymenoptera: Eulophidae) Parasitando Pupas de Bombyx mori L. (Lepidoptera: Bombycidae) de Diferentes Idades. Neotropical Entomology, 38(5), 660-664. http://dx.doi.org/10.1590/S1519-566X2009000500016

Zaché, B., Wilcken, C.F., Dacosta, R.R., \& Soliman, E.P. (2010). Trichospilus diatraeae Cherian \& Margabandhu, 1942 (Hymenoptera: Eulophidae), a new parasitoid of Melanolophia consimilaria (Lepidoptera: Geometridae). Phytoparasitica, 38, 355-357. http://dx.doi.org/10.1007/s12600-010-0108-6.

Zanuncio, J.C., \& Lima, J.O.G. (1975). Ocorrência de Sarsina violascens (Herrich - Scaheffer, 1856) (Lepidoptera:Lymantridae) em eucaliptos de Minas Gerais. Brasil Florestal, 6(23), 48-50. 


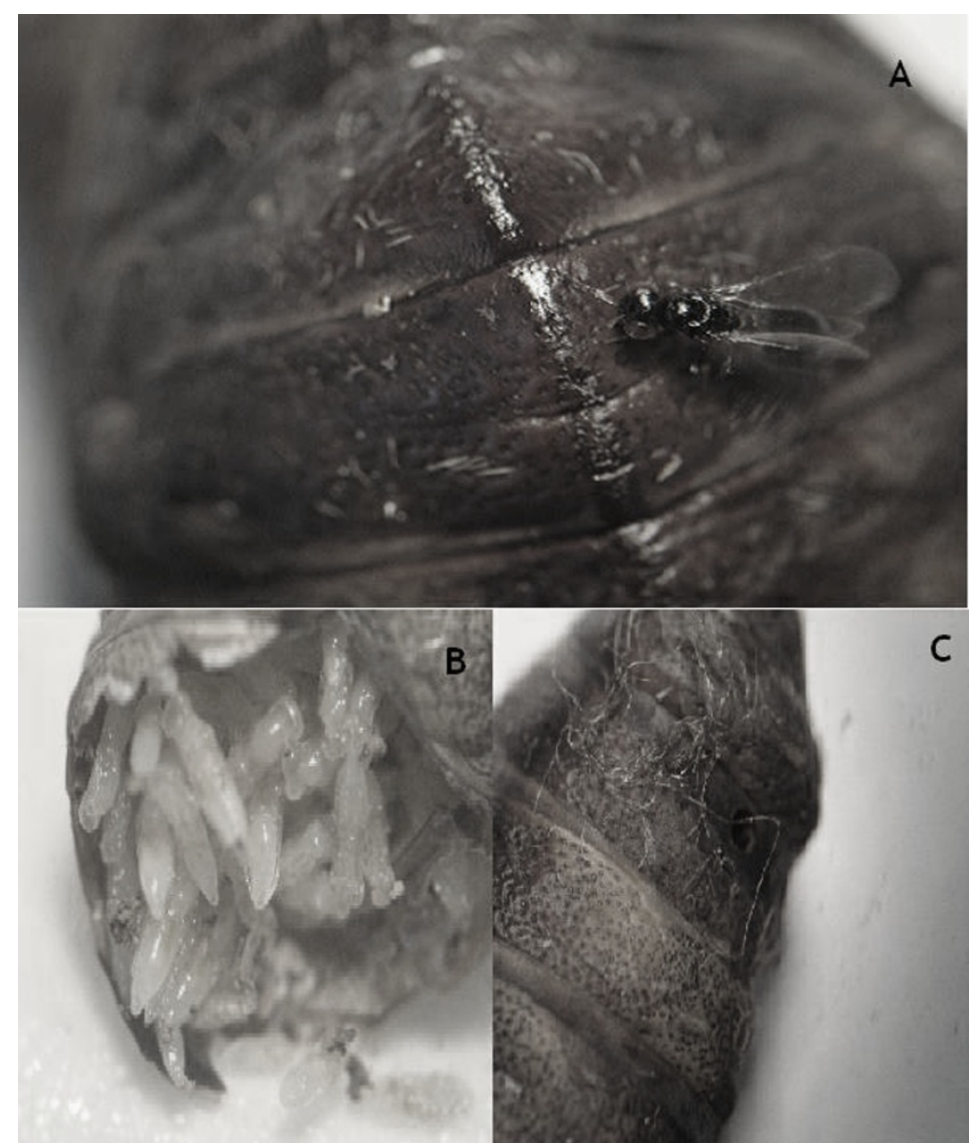

Figure 1. Palmistichus elaeisis female parasitizing a Sarsina violascens pupa (A); parasitoid larvae within the host (B); parasitoid emergence hole (C) 